\title{
ENVIRONMENTAL GOODS AND SERVICES SECTOR
}

\section{Elzbieta Broniewicz}

\author{
Faculty of Civil and Environmental Engineering, Bialystok University of Technology, \\ Wiejska St. 45, 15-351 Bialystok, Poland \\ E-mail: e.broniewicz@pb.edu.pl
}

\begin{abstract}
The main objective of the following paper is to present the Environmental Goods and Services Sector (EGSS) in European Union countries. The Environmental Goods and Services Sector is one of the modules of environmental economic accounts, as satellite accounts in relation to national accounts. The first part of the paper gives an overiew of EGSS definitions and classifications. In second part, the comparison between the EGSS variables in certain EU countries was made. The output, export and employment of the Environmental Goods and Services System were analyzed. The data is presented by environmental protection domains and natural resources managements domains, as well as by economic activity.
\end{abstract}

Keywords: output, environmental economic accounts, environmental goods and services sector, national accounts.

JEL Classification: E61; O44; Q56.

\section{Introduction}

The increased awareness of the need for combating environmental pollution and preserving natural resources has led to an increase in the supply and demand of environmental goods and services, i.e. products to prevent, measure, control, limit, minimise or correct environmental damage and resources depletion. In the context of globalisation, technological change and new political priorities, policy makers have expressed strong interest in the environmental sector. This is widely seen as a sector with great growth potential, generating wealth and creating jobs as well as playing a major role in the transition of economies towards sustainable development (Eurostat 2016; Blazejczak et al. 2009). This industry called the Environmental Goods and Services Sector (EGSS) has become more and more important in many economies (Jensen, Månsson 2012). Given growing global awareness of the importance of environmental sustainability, the demand for environmental goods and services has been increasing rapidly. According to the ITC report, the global market for environmental goods and services was estimated to have reached US\$ 866 billion in 2011 and is expected to rise to US\$ 1.9 trillion by 2020 (Bucher et al. 2014).

The value of EGSS production in the EU from 2000 constanly rise (see Fig. 1).

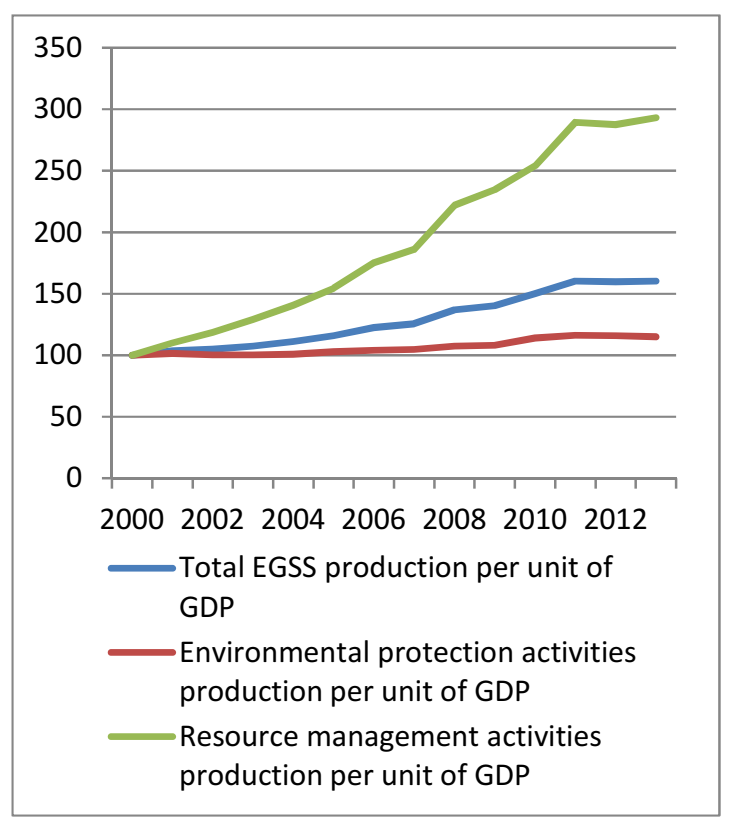

Fig. 1. Trends in environmental protection and resource management output for EU28 (index $2000=100$ ) (Source: own elaboration on the basis of Eurostat Database)

Output of EGS Sector per unit of GDP increased by almost $60 \%$. The output has developed differently in the case of domains related to environmental protection (EP) and resources management (RM). Whereas EP output per unit of GDP 
increased by only $10 \%$ from 2000 to 2012 , RM output grew by more than $150 \%$. The main driving force of the growth of RM was the increase of energy production from renewable sources (e.g. wind and solar power and biofuels) and products for energy and heat savings.

The EGSS indicates how much of the economy is engaged in producing goods and services for environmental protection purposes and resources management activities. There is particular interest in establishing how the economy is moving towards improving and protecting the environment from further deterioration (sustainable development), and the amount of green jobs being created (Fox 2015). Interest in the sector of environmental goods and services was initiated in the early nineties of the twentieth century by Organization for Economic Cooperation and Development (OECD) and the European Commission. In 1999 a joint (OECD and Statistical Office of the European Union Eurostat) manual The Environmental goods and services industry: Manual for data collection and analysis was published. According to this handbook several European Union countries conducted pilot studies, bringing their experience to the Directorate-General for Environment in European Commission, which also conducted research in this area. The results were published in Handbook of the environmental goods and services sector (Eurostat 2009) and in a document entitled Practical guide towards compiling the Environmental Goods and Services Sector (EGSS) statistics (Eurostat 2014). The last document combines two approaches - of the Eurostat (the handbook from 2009) and a global one (e.g. including the United States, the European Commission, the OECD and the World Bank) from 2012, as expressed in a document System of EnvironmentalEconomic Accounting 2012. Central Framework (SEEA) (UN 2014).

The legal basis for the development of sector accounts in goods and environmental services sector (EGSS) in the European Union is the Regulation of the European Parliament and of the Council (EU) No 538/2014 of 16 April 2014 amending Regulation (EU) No 691/2011 on European environmental economic accounts (EC 2014). The Regulation concerns three modules: a module for environmental protection expenditure accounts, a module for physical energy flow accounts and a module for environmental goods and services sector accounts. It requires that statistics on environmental goods and services have to record and present data on production activities of national economy that generate environmental products in a way that is compatible with the data reported under ESA (European System Accounts). Due to its compatibility with the boundaries and definitions used in the national accounts the EGSS database is an indispensable input to microeconomic and macroeconomic analysis of the green economy, environmental and resource policy analysis and the monitoring of policy targets. For most of the countries the EGSS is important for analysing issues related to green growth and green employment.

The analysis of this variables will help to answer a number of questions on different aspects of the environmental goods and services sector such as (Eurostat 2009):

- What is the potential for growth?

- What is the potential for employment creation?

- What has been the evolution in the development and the export of environmental goods and services?

- Is there progress in research and development for cleaner technologies and products?

- What is the progress in the different environmental domains?

- What is the competitiveness of the sector concerning cleaner technologies and products?

- Do the environmental and economic policies have an impact on the sector?

- What is the efficiency of the sector?

This paper presents the Environmental Goods and Services Sector in European Union countries, and includes an analysis of the following variables: output, exports, added value and employment. Among $28 \mathrm{EU}$ countries only 9 have information about EGSS. The information is collected unsystematically. Therefore, in the paper, the data from each country are presented for the last available year.

\section{What is EGSS?}

Environmental-economic accounting provides a means by which information can be organised to assess the relationship between the economy and the environment and how it changes over time. It helps in understanding the amount of economic activity that can be considered related to the environment. Estimates of this amount indicate the extent to which economic units - governments, enterprises, households - are undertaking activities which are beneficial or less harmful to the environment (UNDP 2014). 
The environmental goods and services sector consists of a heterogeneous set of producers of technologies, goods and services who undertake activities to measure, prevent, limit, minimise or correct environmental damage to water, air and soil, as well as problems related to waste, noise and eco-systems. This includes cleaner technologies, goods and services that reduce environmental risk and minimise pollution and resource use (Eurostat 2015a).

Products and services related to environmental protection represent the following categories (Broniewicz 2016):

1) specific services - characteristic activities where the purpose is an environmental purpose - e.g.: wastewater treatment, waste management, organic farming, energy production from renewable resources, monitoring, measurement, education, training, etc.;

2) connected products - services or goods directly serve the environment and have no other use except for environmental protection or resource management;

3) adapted products - goods alternative to tradetional products, which are more environmentally friendly, less polluting or more resource-efficient than equivalent ordinary goods,

4) environmental technologies - technical processes, installations and equipment (goods) as well as methods or knowledge (services), the technical nature or purpose of which is environmental; environmental technologies can be classified as:

- end of the pipe technologies: technical installations and equipment produced for environmental measurements, control. Also they reduce emissions, environmental degradation and resource depletion. These installations operate independently and identifiable parts are added to the production cycles. For example: facilities for specific environmental services (wastewater and waste), equipment for measurement and control;

- integrated technologies: technical processes, methods and knowledge in manufacturing processes are cleaner and less polluting than the equivalent ones in the typical technology used by national producers. For example, in agriculture sector - those that reduce and minimise the negative impact of agriculture on the quality of soil (e.g. organic farming), in industry - those that result in the most eco-efficient industrial processes (e.g. dry ovens compared to wet ovens in cement manufacturing) etc.

These products (i.e. goods and services) and technologies must satisfy the main purpose criterion, i.e. they must have an environmental protection or resource management purpose (hereinafter 'environmental purpose') as their prime objective (Eurostat 2009).

The EGS activity is classified in two main groups (Obst 2010):

I Environmental protection - includes all activities and actions which have as their main purpose the prevention, reduction and elimination of pollution and of any other degradation of the environment. Those activities and actions include all measures taken in order to restore the environment after it has been degraded. EGSS products are broken down by domains in accordance with The Classification of Environmental Protection Activities (CEPA):

1. Protection of ambient air and climate

2. Wastewater management

3. Waste management

4. Protection and remediation of soil, groundwater and surface water

5. Noise and vibration abatement

6. Protection of biodiversity and landscapes

7. Protection against radiation

8. Research and development (R\&D)

9. Other

II Resource management - includes the preservation, maintenance and enhancement of the stock of natural resources and therefore the safeguarding of those resources against depletion EGSS products are broken down by domains in accordance with The Classification of Resource Management Activities (CReMA):

10.Management of water (Opschoor 2006)

11.Management of forest resources, in it: 11A. Management of forest areas, $11 \mathrm{~B}$.

Minimisation of the intake of forest resources

12. Management of wild flora and fauna

13. Management of fossil energy resources, in it: 13A. Production of energy from renewable sources, 13B. Heat/Energy saving and management, 13C. Minimisation of the intake of fossil resources as raw material

14. Management of minerals

15. Research and development (R\&D)

16. Other

The accounts of EGSS consist of the following components: output (including exports), value added and employment. 
The output (measured in current basic prices) is the value of goods and services produced. Value added is the difference between the value of the output and intermediate consumption.

The employment in environmental protection and resource management activities is measured by the full-time equivalent (FTE) employment engaged in the production of the environmental output as defined above. The full-time equivalent is the number of full-time equivalent jobs, defined as total hours worked divided by average annual hours worked in full-time jobs.

Exports consist of sales, barter, or gifts or grants, of environmental goods and services from residents to non-residents.

Output and employment data are widely used indicators for analysing economic sectors and for monitoring their performance and growth (Berck, Hoffman 2002). Gross value added is mainly used to compare the income added by the EGSS to the national income. Export data are important for the evaluation of the competitiveness of an economic sector within the global economy.

\section{EGSS in EU countries}

Total output value of environmental goods and services sector (EGSS) in 28 EU countries in 2013 was equal to 697457 mio euro, which represented $5,1 \%$ of GDP. This value has been growing steadily and has doubled since 2002 (Eurostat Database). The share of EGSS output value in GDP differs between countries, but fluctuates around 5\% (see Table 1). Extremely high share was noticed in Austria $(11,4 \%)$. This may be attributable to the fact that Austria has long traditions and extensive experiences in gathering data concerning EGSS.

Table 1. The share of EGSS variables in GDP [\%] (Source: own elaboration on the basis of Eurostat Database, Fox 2015 and Broniewicz 2015)

\begin{tabular}{l|c|c|c}
\hline \multicolumn{1}{c|}{ Country } & Output & Exports & Value added \\
\hline Bulgaria & 2,5 & $:$ & $:$ \\
\hline Germany & 5,3 & 1,2 & 1,9 \\
\hline France & 3,7 & 0,4 & 1,3 \\
\hline Lithuania & 4,6 & $:$ & 1,5 \\
\hline Luxembourg & 4,0 & 1,4 & 1,7 \\
\hline Netherlands & 5,1 & $:$ & 2,1 \\
\hline Austria & 11,4 & $:$ & $:$ \\
\hline Poland & 4,6 & 1,7 & 2,3 \\
\hline UK & 3,5 & $:$ & 1,7 \\
\hline Romania & 6,9 & 2,0 & 1,5 \\
\hline
\end{tabular}

Note: the latest available year (2011-2014).

Legend: : - data not available.
It can be noted, that the share of exports and value added in GDP between countries is also comparable.

\subsection{Output}

According to Eurostat data, 54\% environmental production value in 2013 was linked to the activities of environmnental protection (CEPA). But in individual countries we can see different production structures (Fig. 2). Environmental protection (CEPA) is the main activity in Romania and France. In Luxembourg and Austria, however, the resource management acivities (CReMA) are leading.

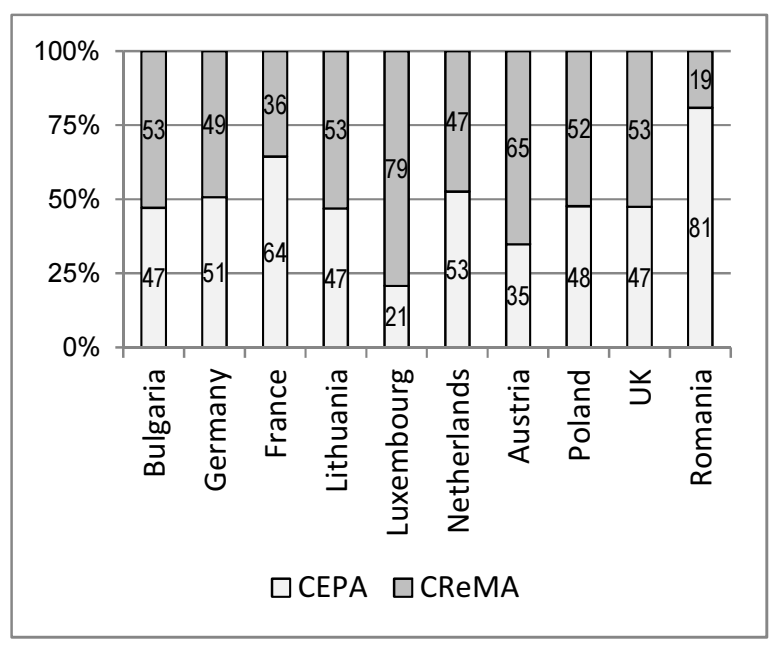

Fig. 2. The structure of EGSS output [\%]

(Source: own elaboration on the basis of Eurostat

Database, Fox 2015 and Broniewicz 2015)

Note: the latest available year (2011-2014).

The output of Environmental Goods and Services Sector consists of:

- market production - involves selling a technology/product at a price that is economically significant, namely the sale covers more than 50 percent of the production costs; the price considered is the price excluding value added tax or subsidies;

- non-market production - provides technologies or products freely or at an economically insignificant price;

- output for own final use - is to be valued at the basic prices of similar products sold on the market or by the total costs of production, e.g. using renewable energy for own final use;

- ancillary production - exists solely to support the main productive activities of an entity by providing goods or services for the use of that entity (Eurostat 2009, 2015b). 
In all analysed cases, the majority concerns market production - average share was $86 \%$. Market activity was carried out in almost all countries in the domain of energy resources management (Fig. 3).

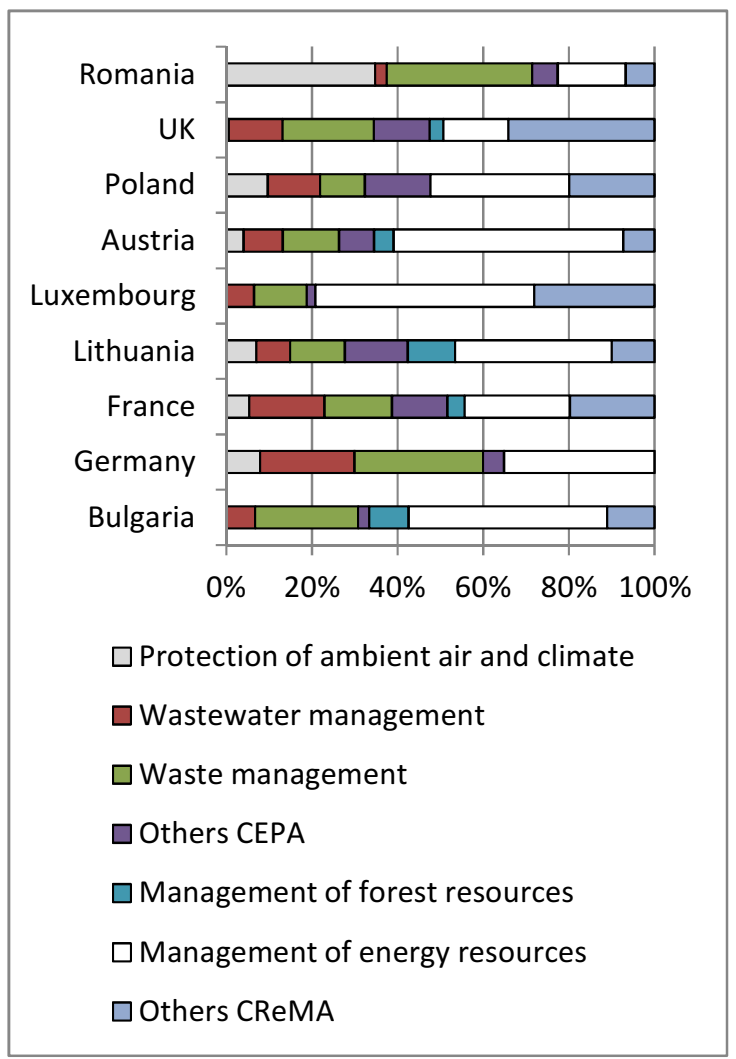

Fig. 3. The structure of EGSS market output by environmental domains [\%]

(Source: own elaboration on the basis of Eurostat Database, Fox 2015 and Broniewicz 2015)

Note: the latest available year (2011-2014).

The share of activities related to the production of energy from renewable sources, heat/energy saving and management and minimisation of the intake of fossil resources as raw material ranged from $24,6 \%$ of market output in France to 53,6\% in Austria. Only in Romania, the largest share was the activities concerning the protection of ambient air and climate.

Looking at the structure of EGSS production by the type of activity (EC 2008) - Figure 4, - one can notice that over the past years, the activities related to electricity, gas, steam and air conditioning supply; water supply; sewerage, waste management and remediation activities had the largest share. This is due to the dominant domain of CReMA, that is, activities related to renewable energy.

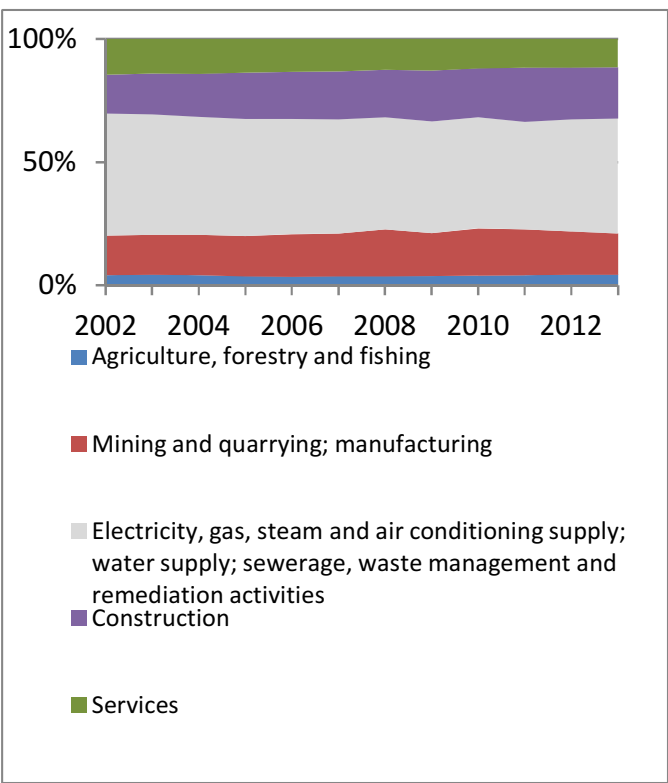

Fig. 4. The structure of EGSS production by economic activity in EU-28 [\%]

(Source: own elaboration on the basis of Eurostat Database)

Analyzing the production of a EGS sector in various EU countries, it can be seen that the highest share of value is production of specific services and adapted products (Table 2). Goods alternative to the traditional products, which are more environmentally friendly are the main direction of production in Romania, Bulgaria and Lithuania.

Table 2. The share of EGSS output [\%]

(Source: own elaboration on the basis of Eurostat Database)

\begin{tabular}{|c|c|c|c|c|c|}
\hline Categories & 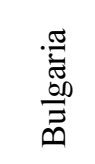 & 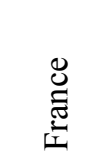 & 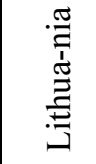 & 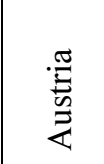 & 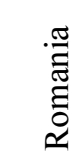 \\
\hline Specific services & 46,0 & 50,9 & 41,6 & 44,6 & 20,4 \\
\hline Connected goods & 3,4 & 13,3 & 9,2 & 4,5 & 11,0 \\
\hline Adapted goods & 50,2 & 27,1 & 45,0 & 30,6 & 66,0 \\
\hline $\begin{array}{l}\text { End-of-pipe } \\
\text { technologies }\end{array}$ & 0,3 & 5,7 & 3,0 & 4,5 & 1,2 \\
\hline $\begin{array}{l}\text { Integrated } \\
\text { technologies }\end{array}$ & 0,3 & 3,0 & 1,2 & 15,7 & 1,5 \\
\hline Total & 100,0 & 100,0 & 100,0 & 100,0 & 100,0 \\
\hline
\end{tabular}

Note: the latest available year (2011-2012).

However, the value of EGSS production in those countries is much lower than in France and Austria (Fig. 5). In the countries of Western Europe, the main category of production are specific 
services. You may also notice a greater share of technologies. In Austria, more than $15 \%$ of the production value are the desired integrated technologies.

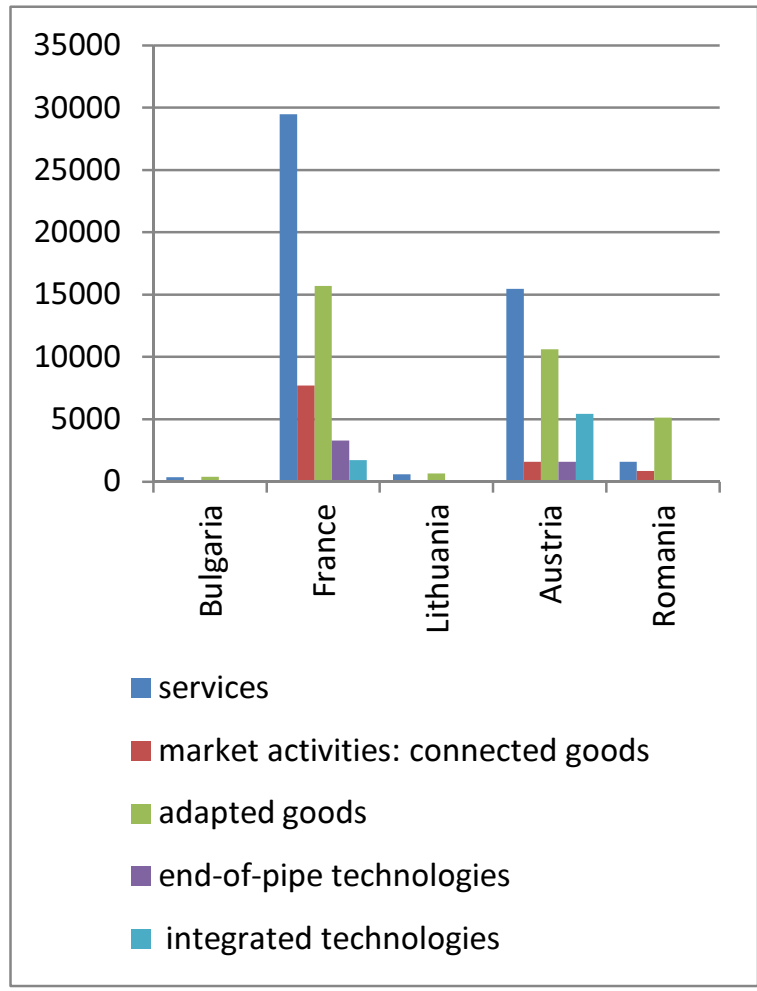

Fig. 5. The value of EGSS output in EU countries [mio euro]

(Source: own elaboration on the basis of Eurostat Database)

Note: the latest available year (2011-2012).

\subsection{Value added}

The value added of the Environmental Goods and Services Sector in the EU-28 rose from 1.5\% of GDP in 2000 to $2.1 \%$ of GDP in 2012. In 2012 that was approximately $40 \%$ of the production value of the sector. The structure of the value added by groups of activity (CEPA or CReMA) is shown in Figure 6 . This structure is generally coincident with the structure of the EGSS production (compare Fig. 2).

\subsection{Export}

The export concerns both products for environmental protection and resource management. Luxembourg is the largest exporter (36\% of total EGSS output), the smallest part of its production is exported by France (less than 10\%). Figure 7

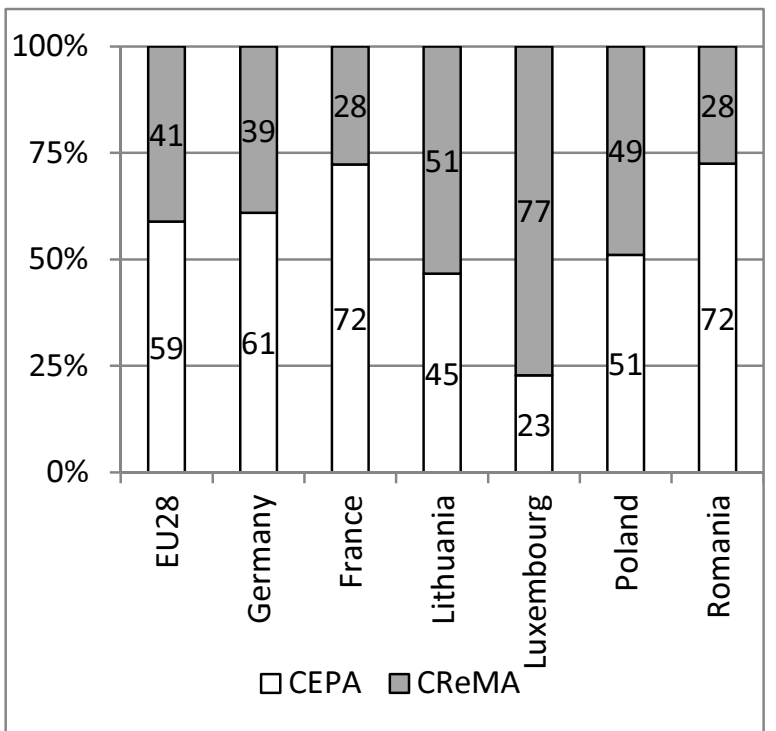

Fig. 6. The structure of EGSS value added in EU countries [\%]

(Source: own elaboration on the basis of Eurostat Database and Broniewicz 2015)

Note: the latest available year (2011-2014).

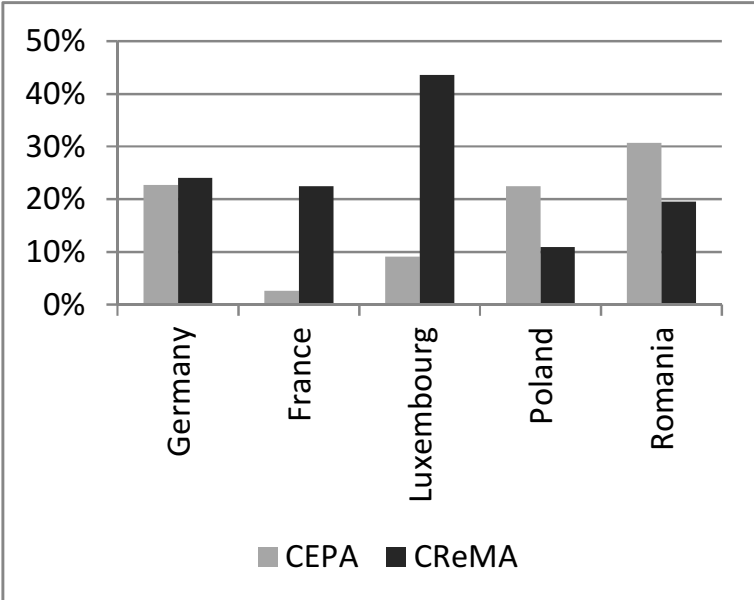

Fig. 7. The share of EGSS export in EGSS output value in EU countries [\%]

(Source: own elaboration on the basis of Eurostat Database and Broniewicz 2015)

Note: the latest available year (2011-2014).

shows the structure of exports according to the main EGSS product groups - environmental protection and resource management.

In Germany, France and Luxembourg we can notice the excess of export of resource management products. In Poland and Romania, goods and services of environmental production are the main exported products. 


\subsection{Employment}

The employment in EU-28 in EGS Sector increased by $41,2 \%$ and reached 4,16 mio persons in 2013. The share of EGSS employment in total employment in EU-28 and different countries is shown in Figure 8.

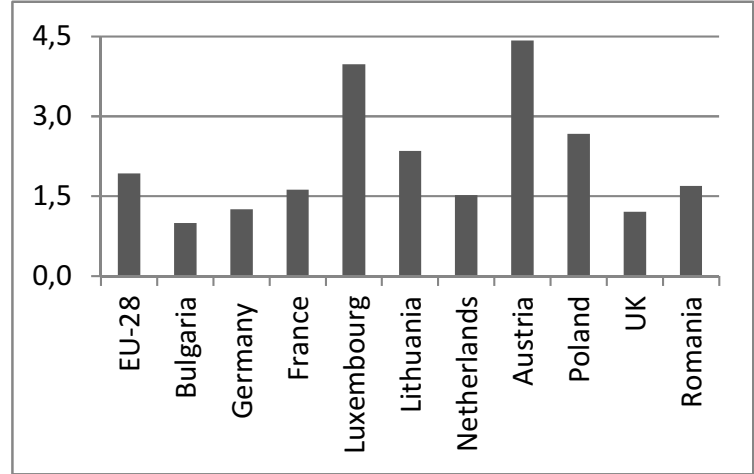

Fig. 8. The share of EGSS employment in total employment in EU countries [\%]

(Source: own elaboration on the basis of Eurostat Database; Fox 2015; Livesey 2010; UK EA 2015; Broniewicz 2015)

Note: the latest available year (2011-2014).

Unfortunately, there are no data about employment in both groups - environmental protection activities and resource management activities. For example, data from United Kingdom shows, that EGSS employment between 2010 and 2012 in environmental protection activities remained stable, but employment in resource management activities grew (Fox 2015). It was mainly a result of increases in water management, renewable energy production, energy efficient products and management of minerals.

\section{Conclusions and future work}

The information on the EGS sector presented in the article, show the similarities and differences in the individual countries. In most EU countries, the EGSS output fluctuates around $5 \%$ of GDP. The exception is Austria, where EGSS production represents $11 \%$ of GDP. It can be noticed that in developed countries, most of the production and export of goods and services is related to the resource management, and not to the environmental protection. About $1.6 \%$ of all EU workers work in the EGS sector, and this share is constantly growing. It can be concluded that this sector will grow steadily in the next years.

It is hoped that, given the legal regulations, the EU will develop EGSS accounts. This would allow to produce a longer time series, where data sources will make it possible to assess how the EGSS has developed.

\section{Disclosure Statement}

The author ensures that there are no competing financial, professional, or personal interests from other parties.

\section{References}

Berck, P.; Hoffman, S. 2002. Assessing the employment impacts of environmental and natural resource policy, Environmental and Resource Economics 22: 135-140. Available from Internet:

http://bazy.pb.edu.pl:2122/static/pdf/444/art\%253 A $10.1023 \% 252$ FA\%253A1015531702905.pdf?ori ginUrl=http\%3A\%2F\%2Flink.springer.com\%2Far ticle $\% 2 \mathrm{~F} 10.1023 \% 2 \mathrm{FA} \% 3 \mathrm{~A} 1015531702905 \&$ toke $\mathrm{n} 2=$ exp $=1458299800 \sim$ acl $=\% 2 \mathrm{Fstatic} \% 2 \mathrm{Fpd} \mathrm{f} \% 2 \mathrm{~F} 4$ 44\%2Fart\%25253A10.1023\%25252FA\%25253A1 015531702905.pdf\%3ForiginUrl\%3Dhttp\%253A $\% 252 \mathrm{~F} \% 252$ Flink.springer.com $\% 252$ Farticle $\% 25$ 2F10.1023\%252FA\%253A1015531702905* hma $\mathrm{c}=1 \mathrm{dd} 411 \mathrm{e} 1309 \mathrm{~b} 0 \mathrm{fb} 6 \mathrm{a} 76 \mathrm{~d} 48196 \mathrm{a} 0 \mathrm{~d} 7720241026 \mathrm{f8}$ f721509708d09481c91a3c07

Blazejczak, J.; Braun, F.; Edler, D. 2009. Global demand for environmental goods and services on the rise: good growth opportunities for german suppliers, German Institute for Economic Research: Weekly Report 5(20) 4. Available from Internet:

http://www.diw.de/sixcms/detail.php?id=334081

Broniewicz, E. 2016. Environmental goods and services sector in Poland, Argumenta Oeconomica (in printing).

Broniewicz, E. 2015. Raport z projektu pilotażowego rachunków sektora wyrobów i usług środowiskowych w Polsce w 2014 r. (ang. Report of pilot Project - EGSS Accounts in Poland In 2014), Bialystok 2015: 4-15.

Bucher, H.; Drake-Brockman, J.; Kasterine, A.; Sugathan, M. 2014. Trade in environmental goods and services: opportunities and challenges. International Trade Centre Technical Paper, Geneva: 9 [online], [cited 04 February 2016]. Available from Internet:

http://www.intracen.org/uploadedFiles/intracenorg /Content/Publications/AssetPDF/EGS\%20Ecosyst ems\%20Brief\%20040914\%20-\%20low\%20res.pdf

EC. 2008. Statistical classification of economic activities in the European Community NACE, Rev. 2, European Communities, Luxembourg.

EC. 2014. The Regulation of the European Parliament and of the Council (EU) No 538/2014 of 16 April 2014 amending Regulation (EU) No 691/2011 on 
European environmental economic accounts (L 158, 27.5.2014).

Eurostat Database. 2016 [online], [cited 02 February 2016]. Available from Internet: http://ec.europa.eu/eurostat/data/database

Eurostat. 2009. Handbook of the environmental goods and services sector. Luxembourg, 25-38 [online], [cited 04 February 2016]. Available from Internet: http://ec.europa.eu/eurostat/web/environment/meth odology

Eurostat. 2014. Practical guide towards compiling the Environmental Goods and Services Sector (EGSS) statistics. Luxembourg, 9-17 [online], [cited 04 February 2016]. Available from Internet:

http://ec.europa.eu/eurostat/web/environment/meth odology

Eurostat. 2015a. EGSS list of environmental products based on CPA and $C N-2015$. Available from Internet:

http://ec.europa.eu/eurostat/web/environment/meth odology

Eurostat. 2015b. Questionnaire Environmental Goods and Services Sector (EGSS), Eurostat, Available from Internet: http://ec.europa.eu/eurostat/web/ environment/methodology

Eurostat. 2016. Environmental goods and services sector. Eurostat Statistics Explained/ [online], [cited 02 February 2016]. Available from Internet: http://ec.europa.eu/eurostat/statistics-explained/index. php/Environmental goods and services sector

Fox, H. 2015. UK environmental goods and services sector (EGSS): 2010-2012. Statistical Bulletin, Office for National Statistics, London [online], [cited 02 February 2016]. Available from Internet: http://www.ons.gov.uk/ons/rel/environmental/ukenvironmental-accounts/goods-and-services- sector--egss---2010-2012/uk-environmental-goodsand-services-sector--egss---2010-2012.html

Jensen, P. R.; Månsson H. 2012. The environmental goods and service sector in Denmark. A pilot study. Statistics Denmark, Copenhagen.

Livesey, D. 2010. Measuring the environmental goods and services sector, Economic \& Labour Market Review, Dec. 2010: 45. Available from Internet: ww.ons.gov.uk/economy/environmentalaccounts/b ulletins/ukenvironmentalaccounts/2015-04-15

Obst, C. 2010. Outcome paper for global consultation, Issue 5: Environmental Goods and Services Sector, SEEA Editor, Department of Economic and Social Affairs, Statistics Division, United Nations: 2-6. [online], [cited 02 February 2016]. Available from Internet: http://unstats.un.org/unsd/envaccounting/ seearev/OCdocs/Outcome5.pdf

Opschoor, J. B. 2006. Water and merit goods, International Environmental Agreements: Politics, Law and Economics 6(4): 423-428.

UK Environmental Accounts: 2015, Stastistical biuletin, Office of National Statistics, London: 50-53, Available from Internet: http://www.ons.gov.uk/ economy/environmentalaccounts/bulletins/ukenvir onmentalaccounts/2015-07-09

UN. 2014. System of environmental-economic accountting 2012 - central framework. United Nations, New York [online], [cited 04 February 2016]. Available from Internet: http://unstats.un.org/unsd/ envaccounting/seeaRev/SEEA_CF_Final_en.pdf

UNDP. 2014. Measuring the environmental goods and services sector: issues and challenges. Working Paper No. 1 [online], [cited 02 February 2016]. Available from Internet: http:/www.unep.org/ greeneconomy/portals/88/documents/WorkingPap erEGSSWorkshop.pdf 